\title{
The Inclusion of Forest Hydrological Services in the Sustainable Development Strategy of South Korea
}

\author{
Jean-Lionel Payeur-Poirier ${ }^{1}$ (D) and Trung Thanh Nguyen ${ }^{2, *}$ \\ 1 Department of Hydrology, Bayreuth Center of Ecology and Environmental Research (BayCEER), \\ University of Bayreuth, 95440 Bayreuth, Germany; jean.lionel.payeur.poirier@gmail.com \\ 2 Institute for Environmental Economics and World Trade, Leibniz University Hannover, \\ Königsworther Platz 1, 30167 Hannover, Germany \\ * Correspondence: thanh.nguyen@iuw.uni-hannover.de; Tel.: +49-511-762-4827
}

Received: 30 May 2017; Accepted: 15 August 2017; Published: 19 August 2017

\begin{abstract}
In the last decade, the South Korean government has implemented an unprecedented series of plans and policy actions to promote sustainable development, including the National Strategy for Green Growth. Some of these initiatives were direct responses to the evolving challenges in the water sector, and put forest hydrological services into perspective. To a certain extent, water was managed within a wider environmental context through the combination of forest and water management. However, the efforts to enhance forest hydrological services did not correspond to the immense potential of forests for the achievement of sustainable water management. We present a comprehensive and current view of the major challenges and opportunities related to forest hydrological services in South Korea. We identify key forest hydrological services in view of the major biophysical, environmental, and economic challenges in the water sector. We propose guidelines for the enhancement of forest hydrological services and for a better inclusion of these services in South Korea's sustainable development strategy. An increased contribution of forests to the provision of high-quality water in sufficient, regulated amounts, and to the preservation of a safe environment in regards to natural hazards is imperative for the long-term development of South Korea.
\end{abstract}

Keywords: ecosystem services; green growth; forest and water management; Four Major Rivers Restoration Project

\section{Introduction}

The importance of forests for the provision of water-related benefits is continuously increasing [1,2]. In many parts of the world, forest hydrological services have significantly contributed to sustainable development, and measures for their preservation and enhancement have been included in national development strategies. In 2008, the Republic of Korea (hereinafter referred to as South Korea) defined sustainable development as one of its primary missions. The creation of the Presidential Commission on Sustainable Development and the subsequent Presidential Commission on Green Growth initiated the development of sector-based strategies, which resulted in the implementation of numerous initiatives for the sustainable development of the nation. The National Strategy for Green Growth implemented in 2009 is the most comprehensive environmental plan that South Korea has ever implemented [3]. The Strategy follows the international principles of green growth, and South Korea is innovating in this field [4]. The three main objectives of the Strategy are (i) to mitigate climate change and enhance energy independence; (ii) to create new engines for economic growth; and (iii) to improve the quality of life and enhance the international standing of the nation [5]. In the short-term, the Strategy aims at stimulating job creation and revitalizing the economy. In the mid- and long-term, it aims at achieving the sustainable management of the nation's natural resources. Two of the major sectors of 
the Strategy are forest and water. Although forests usually reduce the amount of water available for use by the process of transpiration, they can enhance water supply by the capture of precipitation, the regulation of water flow, and the preservation or improvement of water quality, among other processes [6,7]. In this sense, forests can play an important role in the sustainable management of water. Since forests account for $61.1 \%$ of the land cover of South Korea [8], their consideration and use for the achievement of sustainable water management is highly pertinent. We believe that this should be reflected in an adequate inclusion of forest hydrological services in the National Strategy for Green Growth.

Due to the increasing urbanization and industrialization of the country, to the high population density, to the mountainous topography, to the seasonal precipitation regime, to agricultural intensification in highland areas, and to an overuse of chemical fertilizers, the South Korean water resources have been under pressure. South Korea's rapid economic growth was achieved at a cost to the environment $[9,10]$. It is partly responsible for the aggravation of problems in the temporal regulation of water supply and the preservation of water quality. In fact, municipal, industrial, and agricultural pollution related to organic nitrates and phosphates has been identified as the most serious environmental issue [11]. The increasing concentration of these nutrients in rivers, lakes, and reservoirs has led to the eutrophication of surface and coastal waters [12,13].

The recent shift operated by the government from quantity-oriented growth to green growth has put forest hydrological services into perspective. To a certain extent, the nation has recognized the contribution of forests towards sustainable water management by including reforestation and forest management in projects such as the Four Major Rivers Restoration Project (FMRRP). This project was first implemented in the Han River basin, which is considered the heart of South Korea due to its population and the ecosystem services it provides to the population [14]. The supply of water by the Han River basin is an ecosystem service that is highly valued by a significant proportion of the South Korean population [15]. Nature and man have endowed the basin with many reservoirs, lakes, and rivers of which the watersheds are mostly covered by forests. These watersheds are the main sources of freshwater for the Seoul Capital Area. The basin provides additional services, such as food, erosion prevention, carbon sequestration and storage, habitat for species, local climate air quality, recreation, and tourism [16]. The Han River basin is a good example of a socio-ecological system, where agricultural production and the supply of high-quality water to downstream regions are highly valued and desired, but sometimes opposed $[17,18]$. Initiatives such as payments for ecosystem services have helped to improve the situation, not only in terms of environmental conditions, but also in terms of human health and wealth distribution $[4,19]$. Public engagement in sustainable development was solicited by the government, and the nation positively responded and acted at all levels [20].

However, in most parts of the country, problems of water supply and quality still emerge or have worsened from the effects of climate change and changes in land cover and land use [21,22]. The prospect of future increasing hydroclimatic variability stresses the importance of these problems in policy and scientific agendas. Further opportunities to regulate water supply and improve water quality through improved and expanded forest management are at hand [23-25]. Unfortunately, the increased pressure on water resources has fuelled conflicts between stakeholders [26]. Moreover, various stakeholders have raised criticism towards the motives, the content, and some of the results of the FMRRP [27]. We believe that this should be taken into account in the future development of policy and scientific agendas.

In the current article, we review the forest hydrological services in South Korea and their inclusion in the national sustainable development strategy. We rely on the wealth of articles, reports, and documents published in the recent past to derive a comprehensive view of the major challenges and current opportunities. This review concerns the following questions: (i) in South Korea, what are the most essential (i.e., key) hydrological services that can be provided by forests, and (ii) are these key forest hydrological services appropriately included in the sustainable development strategy? Our answers to these questions should provide information and suggestions to policy-makers, scientists, 
and other stakeholders engaged in the sustainable management of forests and water in South Korea. We also aim to promote reflection on the current issues.

\section{Major Challenges in the Water Sector}

The hydrological regime of South Korean water bodies displays a pronounced seasonality, as the climate of South Korea is characterized by cold and dry winters, and hot and moist summers [28]. More than $60 \%$ of the annual rainfall is concentrated in the summer months and related to the occurrence of the East Asian summer monsoon (EASM), of which the precipitation regime is characterized by heavy rainfall events [29]. The mountainous topography of South Korea also contributes to this pronounced seasonality, as water rapidly flows from steep slopes of short lengths and shallow soils to streams and rivers of short reaches and steep channels [28]. Although the annual rainfall of South Korea is $\sim 60 \%$ higher than the global average, water availability per capita is only $\sim 12 \%$ higher and is lower than the average for OECD countries [30-33]. This discrepancy can be partly explained by the complexity of water management in conditions of large flow magnitude. In fact, such conditions have resulted in relatively frequent floods and droughts in South Korea [32,34]. The severity of floods and droughts is highly variable, as the EASM exhibits a substantial interannual variability in intensity [35]. Eighteen droughts have occurred over the last 100 years, with severe droughts occurring in seven-year cycles since 1994 (Table 1). Over the last decade, the annual average damage caused by floods amounted to $\sim 1.1$ billion U.S. dollars (USD) (Figure 1).

Table 1. Droughts and associated damages since 1990 (from Ishiwatari et al. (2016) [32]).

\begin{tabular}{cc}
\hline Year & Damages \\
\hline $1994-1995$ & Limited water supply for 222,000 persons in 86 cities and counties \\
2001 & Limited water supply for 304,815 persons in 86 cities and counties \\
2002 & Limited water supply for 92,838 persons in 23 cities and counties \\
$2008-2009$ & Limited water supply for 228,068 persons \\
\hline
\end{tabular}

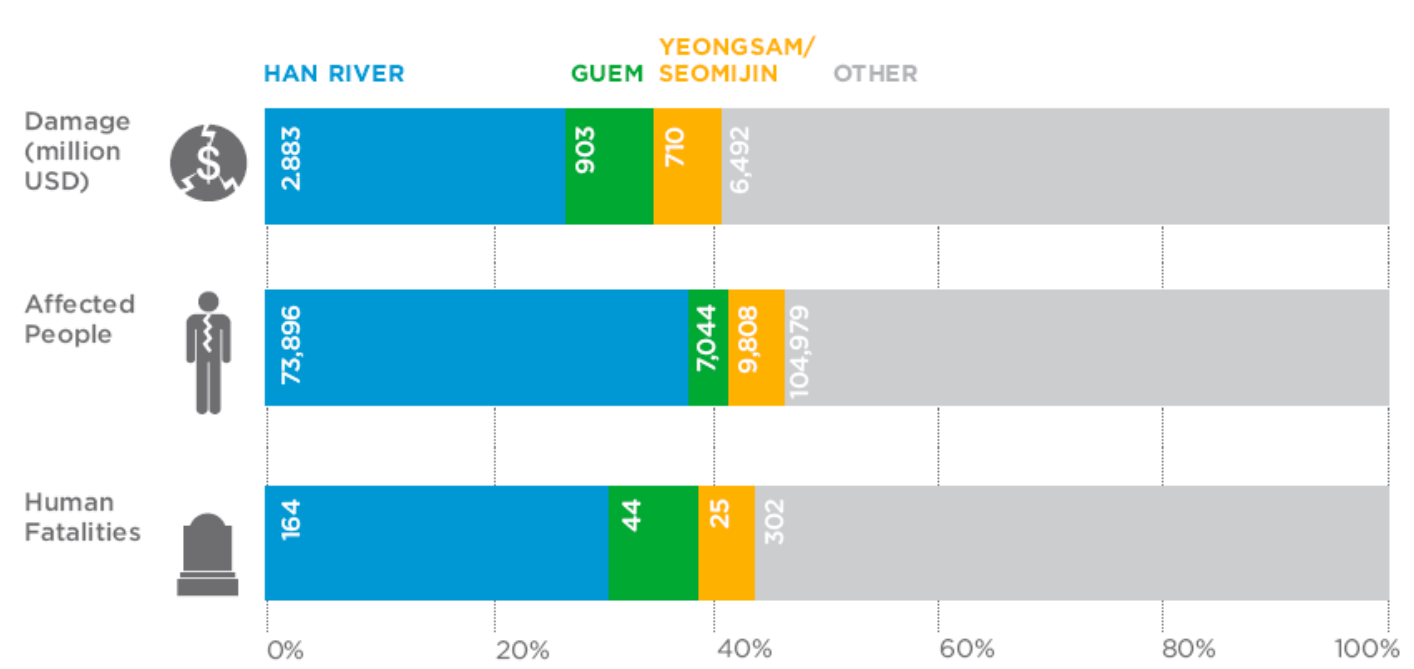

Figure 1. Flood damage over the last decade (from Ishiwatari et al. (2016) [32]).

In recent decades, changes in the climate of South Korea have been observed, namely an above-global-average increase in surface temperature, and a substantial increase in the frequency and intensity of heavy rainfall events [36-38]. From 1954 to 1999, surface temperature increased at a rate of $0.23{ }^{\circ} \mathrm{C}$ per decade, and from 2001 to 2010 , at a rate of $0.5^{\circ} \mathrm{C}$ per decade [35]. Choi et al. (2008) [39] reported that, in the region of the Lake Soyang watershed, the precipitation of extremely wet days increased by 61 to $80 \mathrm{~mm}$ per decade over the period from 1973 to 2007 . The observed changes are 
predicted to intensify until at least 2100 , along with an increase in the occurrence and severity of floods and droughts [40-43]. The United Nations has projected that, in terms of water availability, the Seoul Capital Area will be under very severe water stress by $2050\left(<500 \mathrm{~m}^{3}\right.$ of freshwater per capita per year) [44].

South Korea is highly dependent on its $\sim 18,000$ reservoirs for its water supply. In recent decades, increasing trends of sediment load, nutrient load, and consequent sedimentation and eutrophication of some of the major reservoirs have been observed. These trends are related to increasing rates of soil erosion and nonpoint source pollution [21,45]. In 2003, between $42.4 \%$ and $68.7 \%$ of the total pollutant load of the four major rivers originated from nonpoint sources (based on data of biological oxygen demand (BOD)) [46]. As a matter of fact, the development of agriculture in highland areas has been a major factor in the increase in sediment and nutrient loads. In these areas, steep slopes prevail and a change in land cover from forest to agricultural field, concurrent with the tilling of the land, is usually followed by a substantial increase in the average rate of soil erosion [47]. In addition, the high levels of fertilizer application practiced and the production of animal manure result in the massive input of nutrients to water bodies. There is a strong seasonality in the input of nutrients and sediment to reservoirs, as rates substantially increase in response to heavy rainfall events of the EASM $[21,48,49]$. Accordingly, changes in the water balance components of watersheds from the aforementioned increases in extreme hydroclimatic conditions have also contributed to the increase in sediment and nutrient loads [50]. The combined effects of changes in land cover, land use, and climate have had and are predicted to continue having considerable and negative impacts on the South Korean water resources [51-53].

Highland agricultural intensification has not only caused water pollution but also led to increasing water use conflicts between stakeholders of highland and lowland areas. The public distrust of national and local governments has also been increasing [54]. A water use charge was imposed in 1999 on downstream users to pay for upstream farmers to preserve water quality. The charge was increased with time, from $80 \mathrm{KRW} / \mathrm{m}^{3}$ in 1999 to $170 \mathrm{KRW} / \mathrm{m}^{3}$ in 2012, but upstream farmers have declared that the payments do not correspond to their efforts. Meanwhile, downstream users have claimed that, due to water quality problems, upstream farmers should not be compensated. Downstream users have also raised concern that money raised by the charge has not been used in an efficient way by national and local authorities [26,54]. Another issue is the water pricing mechanism. It has been claimed that South Korean water is priced without a complete overview and consideration of all costs and environmental externalities [54]. The average national price of tap water has increased on average by $5.4 \%$ per year, from $211 \mathrm{KRW} / \mathrm{m}^{3}$ in 1991 to $660 \mathrm{KRW} / \mathrm{m}^{3}$ in 2013, and the production costs have increased by an average of 5.6\% per year, from $260 \mathrm{KRW} / \mathrm{m}^{3}$ in 1991 to $849 \mathrm{KRW} / \mathrm{m}^{3}$ in 2013 [54]. Thus, the average price in 2013 covered only $~ 80 \%$ of the production costs. This underpricing mechanism has resulted in an excessive use of water, which increases pressure on the resource. In fact, the South Korean daily water use per capita is 1.2 times higher than that of the United Kingdom, 2 times higher than that of France and Germany, and 2.5 times higher than that of Denmark [54].

To summarize, South Korea is faced with evolving challenges in the water sector. These include, among others: (i) the biophysical and environmental challenges of a monsoon climate, a mountainous topography, and climate change; (ii) increasing rates of water pollution due to changes in land cover and land use (related to the rapid economic growth of the country); and (iii) an inefficient water policy framework for water pricing and water use. It should also be noted that many hydrological services are considered public services, which implies nonrivality and nonexcludability [55]. The exclusion of these principles can lead to the underestimation of service value, to free-riding, undersupply, over use, and finally, to exploitation and environmental damage.

\section{Key Forest Hydrological Services}

Forests can provide a plethora of hydrological and other ecosystem services. These services are not independent of each other and their relationships may be highly nonlinear [56,57]. Attempts 
to enhance a single service often lead to gains (synergies) or losses (tradeoffs) in other services [58]. Nevertheless, in order to establish priorities and define targeted policy actions, key (i.e., most essential) forest hydrological services must be identified. In view of the major challenges and the persistent public demands for a greater improvement of environmental conditions [59], we consider that the key forest hydrological services in South Korea are (i) water supply; (ii) the preservation of water quality and the purification of water; (iii) the regulation of water flow; and (iv) the prevention and moderation of natural hazards (Table 2). Except for water supply, which is considered a provisioning service, these are defined as regulating services [60]. The specific benefits associated to these services fill the most urgent needs in terms of improvement in the water sector, and relate mostly to the first and third objectives of the National Strategy for Green Growth (refer to Section 1).

The provision of these key services is directly related to certain forest functions (Table 2). Water supply and quality can be influenced by both the aerial and underground parts of forests. The influence of the canopy is greatest through the interception of rainfall and solar radiation as well as through transpiration. The interception of rainfall and the process of transpiration reduce the amount of rainfall transferred to soils and groundwater, directly influencing water supply. Rates of interception and transpiration usually vary with forest type and forest density. For example, interception losses are usually much less in a well-thinned deciduous stand than in a dense coniferous stand. The interception of solar radiation can influence water supply by lowering air temperature below the canopy, which consequently reduces rates of evaporation. Rates of snowmelt are also usually reduced by the presence of a canopy, thus regulating water flow in spring. The presence of a canopy can also influence the water quality of streams by regulating the process of eutrophication through the lowering of water temperature. It also reduces the kinetic energy of rainfall, which consequently decreases erosion rates and improves water quality. This is also the case for the presence of an organic layer and debris. The influence of forest soils and the root system of forests is also significant. By creating a network of soil micro- and macropores, the root system increases soil infiltration capacity. This can enhance soil water storage and the recharge of groundwater, which are both closely related to the regulation of water flow. A higher soil infiltration capacity usually results in lower rates of surface runoff, and hence in a reduction in erosion. Erosion can also be reduced by the soil stabilization effect of the root system, especially in riparian and mountainous areas. Improvements in water quality can be achieved by the fauna of forest soils, as bacteria and other organisms enhance nutrient cycling. This can also reduce the leaching of nutrients to groundwater [61]. Concerning natural hazards, their prevention and moderation by the presence of forests has been widely reported [62]. Chang et al. (2009) [63] reported an association between increasing flood damage and deforestation in a mountainous province of South Korea.

In summary, we consider that in South Korea, forests can greatly contribute to the provision of high-quality water in sufficient, regulated amounts, and the preservation of a safe environment in regards to natural hazards. 
Table 2. Key forest hydrological services associated to forest management measures.

\begin{tabular}{|c|c|c|c|}
\hline Forest Hydrological Services & Specific Benefits & Forest Functions & Forest Management Measures \\
\hline Water supply & $\begin{array}{l}\text { - Domestic, agricultural, and } \\
\text { industrial use } \\
\text { - Enhancement of energy } \\
\text { independence with hydropower }\end{array}$ & $\begin{array}{l}\text { - Recharge of groundwater due to high } \\
\text { soil infiltration capacity }\end{array}$ & $\begin{array}{ll}\text { - } & \text { Avoid soil compaction } \\
\text { - } & \text { Favour well-thinned, deciduous } \\
\text { stands in order to reduce } \\
\text { interception losses }\end{array}$ \\
\hline $\begin{array}{l}\text { Preservation of water quality and } \\
\text { purification of water }\end{array}$ & $\begin{array}{l}\text { - Reduction in sedimentation and } \\
\text { - } \begin{array}{l}\text { eutrophication of reservoirs } \\
\text { - }\end{array} \\
\text { More equal distribution of wealth by } \\
\text { payments for ecosystem services }\end{array}$ & 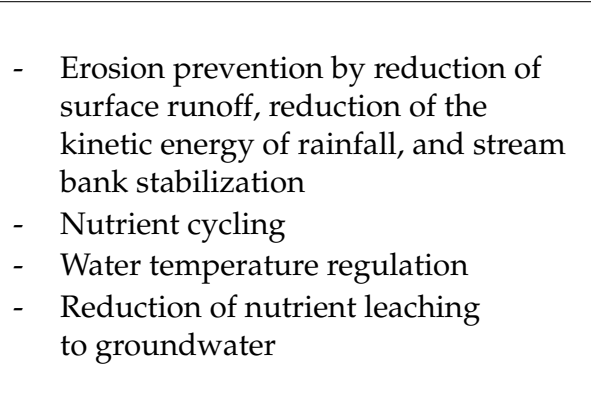 & 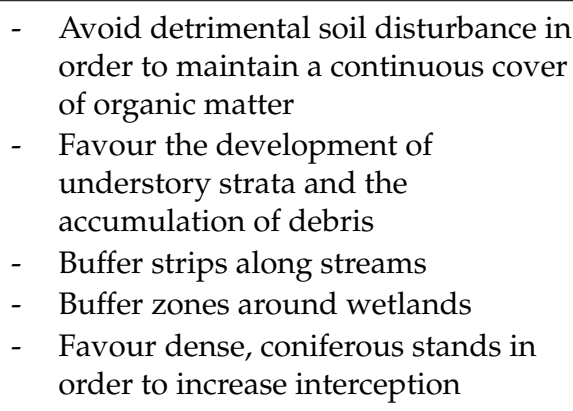 \\
\hline Regulation of water flow & $\begin{array}{l}\text { - } \text { Reduction in costs of water } \\
\text { management measures } \\
\text { - } \quad \text { Mitigation of floods and droughts }\end{array}$ & $\begin{array}{ll} & \text { Water storage in soil } \\
\text { - } & \text { Recharge of groundwater due to high } \\
& \text { soil infiltration capacity } \\
\text { - } & \text { Reduction of water velocity by } \\
\text { percolation through soil } \\
\text { - } & \text { Reduction of snowmelt rate }\end{array}$ & $\begin{array}{ll}\text { - } & \text { Measures to increase soil } \\
& \text { formation rates } \\
\text { - } & \text { Avoid soil compaction } \\
\text { - } & \text { Buffer strips along streams } \\
\text { - } & \text { Buffer zones around wetlands }\end{array}$ \\
\hline $\begin{array}{l}\text { Prevention and moderation of } \\
\text { natural hazards (e.g., landslides } \\
\text { and mudflows) }\end{array}$ & $\begin{array}{ll}\text { - } & \text { Reduction in the number of victims } \\
\text { - } & \text { Reduction in damage } \\
\text { - } & \text { Reduction in restoration costs }\end{array}$ & $\begin{array}{l}\text { - Soil and stream bank stabilization } \\
\text { - } \text { Reduction of water velocity by } \\
\text { percolation through soil }\end{array}$ & $\begin{array}{ll}\text { - } & \text { Reforestation of highland areas } \\
\text { - } & \text { Buffer strips along streams } \\
\text { - } & \text { Avoid soil compaction }\end{array}$ \\
\hline
\end{tabular}




\section{Combination of Forest and Water Management}

Forest management can greatly influence the capacity of forests to provide hydrological services (Table 2). In South Korea, the Forest Act requires the government to produce a National Forest Plan for the management of forests every 10 years. Accordingly, the Plans reflect the views, visions, and strategies of succeeding governments over time. During the 1960s, the government focused on afforestation and forest restoration. Until this decade, forests were degraded because of war, illegal harvest, and uncontrolled shifting cultivation. During the 1980s, it focused on increasing forest stocks to ensure timber supply [64]. As a result, the national forest cover increased from 55\% in 1963 to $64 \%$ in the 1990s and until today [65]. From 1960 to 2010, the growing stock increased by about 13 times, from only $10 \mathrm{~m}^{3} /$ ha in 1960 . However, even though the growing stock increased, the forested area decreased (Table 3). Since 2000, the national percentage area of forests and wooded land has been decreasing by an annual average of $0.1 \%$ (Figure 2 ).

Table 3. Forested area, stock, and growing stock over time (from Lee (2012) [66]).

\begin{tabular}{cccc}
\hline Year & Area (1000 ha) & Stock $\mathbf{( 1 0 0 0 ~ \mathbf { ~ m } ^ { \mathbf { 3 } } )}$ & Growing Stock $\left(\mathbf{m}^{\mathbf{3}} / \mathbf{h a}\right)$ \\
\hline 1960 & 6700 & 63,995 & 9.6 \\
1970 & 6611 & 68,772 & 10.4 \\
1980 & 6567 & 145,694 & 22.2 \\
1990 & 6476 & 248,426 & 38.4 \\
2000 & 6430 & 387,758 & 60.3 \\
2010 & 6369 & 800,025 & 125.6 \\
\hline
\end{tabular}

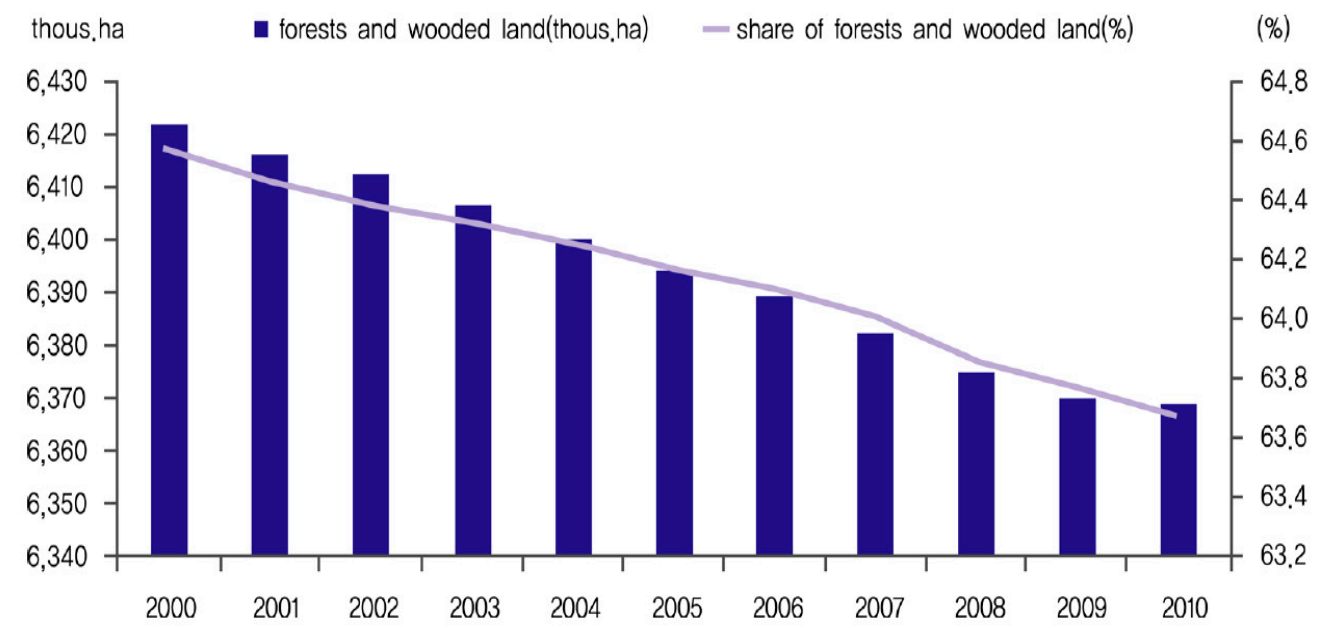

Figure 2. Total area and national percentage area of forests and wooded land over time (from Statistics Korea (2012) [67]).

Since the beginning of the millennium, a gradual shift in forest policy and management towards the provision of multiple ecosystem services has been operated. In order to respond to the major challenges in the water sector, the South Korean government defined a series of policy actions in its National Strategy for Green Growth [5]. Some of the policy actions are directed towards the management of water within the wider context of environmental conservation, including reforestation, forest management, and the protection of forests. Such policy actions, combining forest and water management, were also defined in the Fifth National Forest Plan (2008-2017) [68], the Comprehensive Water Management Plan for the Four Major Rivers [46,69], and the Water Environment Management Master Plan (2006-2015) [70].

The Fifth National Forest Plan was designed for the promotion of sustainable forest management (SFM) through the local-scale application of criteria and indicators of SFM, the expansion of forest 
management certification, the development of a national certification system, and the use of a forest sustainability index. Directly related to forest hydrological services is the SFM indicator of protected forests. Prior to the Plan, between 1990 and 2007, the area of forests protected for soil erosion control decreased from 8968 to 1653 ha. Over the same period, the area of forests protected for the conservation of watersheds increased from 160,634 to 292,472 ha, while the area of forests for the protection of water sources remained stable at $\sim 125,000$ ha [68].

The Comprehensive Water Management Plan for the Four Major Rivers was established as a new system of watershed management for the improvement of water quality. It consisted in the development and implementation of water and watershed management policies, and the establishment of decentralized watershed management bodies. In addition to the funding of projects of stream protection and restoration, it introduced a buffer zone system to reduce nonpoint source pollution. Buffer zones were designated around the major reservoirs as well as along a few other rivers and streams, and a policy to restrict development within the zones was implemented. In 2007, these buffer zones covered a total area of 113,056 ha [68]. Furthermore, the Plan established a land purchase system in which the owners of land located within the buffer zones can voluntarily sell their land to the government. The land is to be managed by the government and land cover is to be converted to forest. In 2005, the area of purchased land totalled 1653 ha [70].

The Water Environment Management Master Plan was developed to meet the public demands of an ecologically healthy water environment. It expanded some of the systems introduced by the Comprehensive Water Management Plan for the Four Major Rivers, and promoted projects of ecosystem restoration and water quality control. Among other measures, the Plan aimed to restore $21,800 \mathrm{~km}$ of non-natural streams into natural streams, and improve the management of buffer zones. It also aimed to convert $30 \%$ of the purchased land into forested riverine ecobelts in order to enhance the connectivity between and within water bodies and buffer zones. An assessment of the progress in reaching the targets set for water quality revealed that, in $2013,80.7 \%$ of the rivers and $12.2 \%$ of the lakes met the targets [71].

Some of the policy actions of the National Strategy for Green Growth were first implemented in the Four Major Rivers Restoration Project (FMRRP; 2009-2013) [69,72]. The FMRRP followed the shift in management structure realised by the Comprehensive Water Management Plan for the Four Major Rivers, and was implemented through the first Five-Year Plan of the Strategy. The budget of the Five-Year Plan corresponded to $~ 10 \%$ of the 2009 gross domestic product (GDP), and the government estimated the production induced by the Plan to $\sim 20 \%$ of the 2009 GDP [73]. The FMRRP was attributed $14.2 \%$ of this budget, and included projects revolving around five core tasks. It introduced a Water Quality Forecasting System at the sixteen weirs that were built on the four rivers, in order for the nation to adapt to extreme conditions and to mitigate their impacts on communities [74]. Through the FMRRP, the construction of hydropower generators by K-water (a governmental company) was promoted, which contributed to energy independence, created employment, and boosted the economy [75,76]. The government also aimed to ecologically restore $1667 \mathrm{~km}$ of streams from 2011 to 2017 through efforts of reforestation in riparian areas [71]. Water quality was improved, as a substantial decrease in BOD was reported following the restoration of streams [77]. To increase the flood-control capacity of the country, 147 wetlands were established for a total area of $12.5 \mathrm{~km}^{2}$ [29]. These efforts were part of the Strategy's policy action of adaptation to climate change [5]. The positive coupling between environmental management and the operation of the newly built hydraulic structures was highlighted by Ahn et al. (2014) [78]. Park et al. (2014) [79] reported a strong positive relationship between the water quality of reservoirs and the proportion of forested area of watersheds. Furthermore, simulations showed an improvement in the regulation of water supply from the combined effects of the measures, taking the effects of climate change into account $[80,81]$. 


\section{Inclusion of Key Forest Hydrological Services in the Sustainable Development Strategy}

The objectives of the National Strategy for Green Growth are in line with those of previous and concurrent environmental plans [59]. However, even though South Korea has committed to a green growth model, the current degree of "greenness" remains debatable. In the face of evolving challenges in the water sector, it is believed that the measures implemented through the FMRRP were not adequately coupled to the long-term objectives of the Strategy, and that the possible contribution of forest hydrological services to sustainable water management was underestimated. According to various stakeholders, the operations of the FMRRP of dredging sediment, installing riverbed filtration facilities, and installing weirs and dams did not entirely follow the principles of green growth, neither at the environmental, nor at the economical, nor at the political level [82-86]. Park (2010) [87] stated that the FMRRP likely induced some habitat destruction. Lee et al. (2016) [88] observed important changes in groundwater flow systems following the construction of weirs, and anticipated gradual changes in groundwater chemistry. A risk assessment at the Nakdong River basin resulted in little future effect of the FMRRP in certain flood-prone regions [89]. In spite of the successes of the FMRRP, the government has been criticized for focusing too much on growth and overlooking the green aspects. In other words, the continued preference for market-driven growth prioritized the economy over the environment $[90,91]$. In order to ensure long-term beneficial effects of the FMRRP, forest management for the enhancement of hydrological services (Table 1) should have been done at a much wider scale, as UNEP (2010) [3] proposed. It should be better integrated into the National Strategy for Green Growth as well as expanded within the Strategy, in order to realize the full potential of forests for the provision of these services. We agree that this may be much more complex than the construction of infrastructure, but are convinced of the willingness of the nation and the capacity of the government to advance in this direction. Also, in order to promote the second objective of the Strategy (refer to Section 1), the government could complement the economic growth generated by infrastructure construction with economic growth generated by forest management.

Choi (2011) [92] provided a very good example of the significant effects of forest management on the long-term water balance of forested catchments (Table 4). Over a period of 28 years, the runoff coefficient of a catchment mostly covered by a coniferous plantation was lower than that of a similar catchment covered by a deciduous forest. This was attributed to the greater rainfall interception capacity of the coniferous plantation. This capacity increased with the age of the plantation, as crown closure also likely increased. In 1996, the coniferous plantation was thinned and crown closure was reduced. This resulted in a notable but temporary increase in the runoff coefficient of the catchment. These observations demonstrate the possible effects of forest management on water quantity and ultimately water management, as well as the dynamic nature of these effects.

Table 4. Runoff coefficient for designated periods in a coniferous and a deciduous forested catchment (from Choi (2011) [92]).

\begin{tabular}{ccc}
\hline Period & Runoff Coefficient Coniferous (\%) & Runoff Coefficient Deciduous (\%) \\
\hline $1982-1986$ & 48.6 & 63.7 \\
$1987-1996$ & 42.4 & 62.2 \\
$1997-2005$ & 61.3 & 61.6 \\
$2006-2009$ & 51.0 & 66.9 \\
\hline
\end{tabular}

The successful measures of reforestation have been a flagship of the National Strategy for Green Growth [66]. Nevertheless, we consider that a proper balance in the enhancement of forest ecosystem services has not yet been achieved. The Fifth National Forest Plan was designed with a focus on "low carbon, green growth" to emphasize and enhance the capacity of forests for carbon sequestration and storage [66]. This followed a period of 16 years during which the national greenhouse gas emissions almost doubled (1990-2005) [93]. We believe that this focus was partly derived from the will to enhance the international standing of the nation. To our knowledge, the enhancement of forest 
hydrological services was not specifically targeted by any of the strategies and action plans presented in the National Forest Plan [68]. In fact, it is stated that a more systematic and practical management of protection forests (for the conservation of soil and water resources) is needed. It is also stated that all protection forests should be defined according to their functions. As Kwon et al. (2008) [94] proposed, the classification of forest functions and the analysis of their spatial arrangement could improve the planning of forest management. In any case, the expansion of protection forests (for the conservation of soil and water resources) would very likely contribute to enhance the key forest hydrological services. It would also likely lessen the consequences of the future predicted forest cover change on the capacity of forests to provide these services [3].

Forest hydrological services should also be enhanced by monetary incentives. In this regard, a primary factor to consider is the ownership of forests. In South Korea, forests can be divided into national forests, public-owned forests, and private-owned forests. National forests account for $\sim 23 \%$ of the total forested land and are managed by the Korea Forest Service. Public-owned forests are possessed by local governments and public organizations, and account for $\sim 8 \%$ of the total forested land. The rest of the total forested land belongs to private entities. Ownership has changed over the last 20 years with a distinct decline in private-owned forests, and a steady increase in national forests (public-owned forests remained stable). Private-owned forests are still dominant, and $90 \%$ of the $\sim 19$ million owners own less than 10 ha of forests. The management of these private-owned forests is still very much oriented towards timber production [95]. To change the scheme, payments for the provision of hydrological services should rival with the profits of timber production. Criticism has been raised towards the fact that this is not the present situation [96]. A possible solution would be the identification of spatial priority areas, in order to provide compensation to areas in a situation of urgency and with high potential for improvement. Kong and Lee (2014) [97] and Nguyen et al. (2013) [98] both realized such an analysis for a region of Vietnam, and concluded that the improved distribution of compensation would likely result in a significant enhancement of forest hydrological services. In particular, Nguyen et al. (2013) [98] reported that increases in the normalized forest cover of a catchment resulting from adequate payments for forest hydrological services would likely be accompanied by important decreases in overland flow and soil sedimentation, as well as important increases in soil-retained water and in the longevity of a reservoir dam (Table 5).

Table 5. Changes in hydrological variables and dam longevity with increasing normalized forest cover in comparison to a scenario of null forest cover (from Nguyen et al. (2013) [98]).

\begin{tabular}{|c|c|c|c|c|}
\hline $\begin{array}{c}\text { Normalized Forest } \\
\text { Cover }(\%)\end{array}$ & 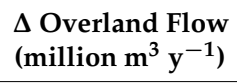 & $\begin{array}{l}\Delta \text { Soil Sedimentation } \\
\quad\left(\text { million } t y^{-1}\right)\end{array}$ & $\begin{array}{c}\Delta \text { Soil-Retained Water } \\
\left(\text { million } \mathrm{m}^{3} \mathrm{y}^{-1}\right)\end{array}$ & $\Delta$ Dam Longevity (y) \\
\hline 30.8 & -842 & -17.3 & 2112 & 34.9 \\
\hline 35.0 & -920 & -19.9 & 2309 & 40.5 \\
\hline 40.0 & -1015 & -21.2 & 2546 & 48.3 \\
\hline 45.0 & -1109 & -23.4 & 2783 & 57.2 \\
\hline 50.0 & -1204 & -25.5 & 3021 & 67.5 \\
\hline 55.0 & -1298 & -27.7 & 3258 & 79.7 \\
\hline
\end{tabular}

\section{Summary}

We presented a comprehensive and current view of the major challenges and opportunities in the South Korean water sector in relation to forest hydrological services. Biophysical, environmental, and economic challenges were described, based on a review of the recent literature. We identified key forest hydrological services, to which we associated forest management measures. The most relevant and recent environmental plans were assessed in terms of the combination of forest and water management, and guidelines were proposed for the enhancement of forest hydrological services.

The challenges that South Korea is now faced with require a well-thought set of measures taking into account the vulnerability of water resources and the key hydrological services. The Four Major Rivers Restoration Project targeted these challenges, and, over a short period of time, achieved progress 
in sustainable water management. However, the completion of the core tasks of this project requires additional efforts [99]. We firmly believe in the immense potential of forests to at least partly overcome the challenges and contribute to the achievement of sustainable water management. Yet, this potential can only be fully realized by a better inclusion and enhancement of forest hydrological services in South Korea's sustainable development strategy. This could be achieved by (i) forest and water management measures better reflecting the long-term objectives; (ii) a balance in the enhancement of forest ecosystem services; and (iii) improvements in payments for the provision of hydrological services. In addition, a better alignment of policy and scientific agendas would likely be beneficial, as well as an increased participation of scientists in the establishment of watershed management schemes [100].

The link between human well-being and the provision of water-related benefits by forests is widely documented [101-106]. In South Korea, the implementation of adequate solutions to the problems of water supply and quality would likely result in a greater provision of water-related benefits to future generations, and is imperative for the long-term development of the nation [100].

Acknowledgments: We acknowledge support from the International Research Training Group TERRECO, which was funded by the German Research Foundation (DFG) at the University of Bayreuth, Bayreuth, Germany, and the Korea Research Foundation (KRF) at Kangwon National University, Chuncheon, South Korea. We also acknowledge support by DFG and Open Access Publishing Fund of Leibniz University Hannover. We thank two anonymous reviewers and the editors for their useful comments.

Author Contributions: Jean-Lionel Payeur-Poirier and Trung Thanh Nguyen wrote the article.

Conflicts of Interest: The authors declare no conflict of interest, and are not affiliated to any political party and/or lobby.

\section{References}

1. Food and Agriculture Organization of the United Nations (FAO). Forests Are Key for High Quality Water Supply. 2011. Available online: http://www.fao.org/news/story/en/item/53391/icode/ (accessed on 1 April 2016).

2. Pettenella, D.; Vidale, E.; Gatto, P.; Secco, L. Paying for water-related forest services: A survey on Italian payment mechanisms. iForest-Biogeosci. For. 2012, 5, 210-215. [CrossRef]

3. United Nations Environment Programme (UNEP). Overview of the Republic of Korea's National Strategy for Green Growth; UNEP DTIE: Geneva, Switzerland, 2010.

4. Min, K.-J.; Shin, T.; Song, W.; Choi, H.; Lee, S.; Rho, H.; Lee, S.; Brewster, M.; Gaillard-Picher, D. Water and Green Growth; K-Water: Daejeon, Korea; World Water Council: Marseille, France, 2015.

5. Presidential Commission on Green Growth-Republic of Korea. Road to Our Future: Green Growth—National Strategy and the Five-Year Plan (2009 2013); Presidential Commission on Green Growth-Republic of Korea: Seoul, Korea, 2009.

6. Andréassian, V. Waters and forests: From historical controversy to scientific debate. J. Hydrol. 2004, 291, 1-27. [CrossRef]

7. Food and Agriculture Organization of the United Nations (FAO). Forests and Water-FAO Forestry Paper 155; FAO: Rome, Italy, 2008.

8. Ministry of Environment. Environmental Statistics Yearbook; Ministry of Environment: Sejong-City, Korea, 2014.

9. Hoang, V.-N.; Nguyen, T.T. Analysis of environmental efficiency variations: A nutrient balance approach. Ecol. Econom. 2013, 86, 37-46. [CrossRef]

10. Organisation for Economic Co-operation and Development (OECD). OECD Factbook 2008; OECD Publishing: Paris, France, 2008.

11. Organisation for Economic Co-operation and Development (OECD). OECD Factbook 2006; OECD Publishing: Paris, France, 2006.

12. Kim, H.J.; Lee, K.S.; Lee, S.S.; Shin, H.B.; Yoon, K.S. Classification of water quality management for agricultural reservoirs in Korea. In Agricultural Water Quality and Water Use: Developing Indicators for Policy Analysis; Parris, K., Jung, P.K., Eds.; OECD: Paris, France, 2004. 
13. Nguyen, T.T.; Hoang, V.-N.; Seo, B. Cost and environmental efficiency of rice farms in South Korea. Agric. Econom. 2012, 43, 367-376. [CrossRef]

14. World Water Assessment Programme (WWAP). The United Nations World Water Development Report 3-Case Study Volume: Facing the Challenges; UNESCO: Paris, France; Earthscan: London, UK, 2009.

15. Lee, S.; Nguyen, T.T.; Kim, H.N.; Koellner, T.; Shin, H.J. Do Consumers of Environmentally Friendly Farming Products in Downstream Areas Have a WTP for Water Quality Protection in Upstream Areas? Water 2017, 9, 511. [CrossRef]

16. Kang, S.; Tenhunen, J. Complex terrain and ecological heterogeneity (TERRECO): Evaluating ecosystem services in production versus water quantity/quality in mountainous landscapes. Korean J. Agric. For. Meteorol. 2010, 12, 307-316. [CrossRef]

17. Raskin, P.; Gleick, P.; Kirshen, P.; Pontius, G.; Strzepek, K. Water Futures: Assessment of Long-Range Patterns and Problems-Comprehensive Assessment of the Freshwater Resources of the World; Stockholm Environment Institute: Stockholm, Sweden, 1997.

18. Lee, S.; Nguyen, T.T.; Poppenburg, P.; Shin, H.J.; Koellner, T. Conventional and partially converted and environmentally friendly agriculture in South Korea: Profitability and factors affecting farmers' choice. Sustainability 2016, 8, 704. [CrossRef]

19. Kwon, O.K.; Park, S.; Jun, Y.J.; Suh, M.J.; Shin, D.H. The integrated management system (Fims) for the Four Major Rivers Restoration Project in South Korea. In Proceedings of the 5th Civil Engineering Conference in the Asian Region and Australasian Structural Engineering Conference, Sydney, Australia, 8-12 August 2010; Engineers Australia: Sydney, Australia, 2010.

20. Lee, M. Greenstart movement. Korea Environ. Policy Bull. 2013, 11, 1-16.

21. Park, J.-H.; Duan, L.; Kim, B.; Mitchell, M.J.; Shibata, H. Potential effects of climate change and variability on watershed biogeochemical processes and water quality in Northeast Asia. Environ. Int. 2010, 36, $212-225$. [CrossRef] [PubMed]

22. Arnhold, S.; Lindner, S.; Lee, B.; Martin, E.; Kettering, J.; Nguyen, T.T.; Koellner, T.; Ok, Y.; Huwe, B. Conventional and organic farming: Soil erosion and conservation potential for row crop cultivation. Geoderma 2014, 219-220, 89-105. [CrossRef]

23. Ciccarese, L.; Mattsson, A.; Pettenella, D. Ecosystem services from forest restoration: Thinking ahead. New For. 2012, 43, 543-560. [CrossRef]

24. Masiero, M.; Secco, L.; Pettenella, D.; Brotto, L. Standards and guidelines for forest plantation management: A global comparative study. For. Policy Econom. 2015, 53, 29-44. [CrossRef]

25. Mathews, J.A. Green growth strategies-Korean initiatives. Futures 2012, 44, 761-769. [CrossRef]

26. Choi, I.; Kim, H.; Shin, H.; Tenhunen, J.; Nguyen, T.T. Willingness to pay for a highland agricultural restriction policy to improve water quality in South Korea: Correcting anomalous preference in contingent valuation method. Water 2016, 8, 547. [CrossRef]

27. Tockner, K.; Bernhardt, E.S.; Koska, A.; Zarfl, C. A global view on Future Major Water Engineering Projects. In Society-Water-Technology; Hüttl, R.F., Bens, O., Bismuth, C., Hoechstetter, S., Eds.; Springer: Heidelberg, Germany, 2016; pp. 47-64.

28. Shin, J.-H. Ecosystem geography of Korea. In Ecology of Korea; Lee, D.W., Jin, V., Choe, J.C., Son, Y.H., Lee, H.-Y., Hong, S.K., Ihm, B.-S., Eds.; Bumwoo: Seoul, Korea, 2002; pp. 19-46.

29. Yihui, D.; Chan, J.C. The East Asian summer monsoon: An overview. Meteorol. Atmos. Phys. 2005, 89, 117-142. [CrossRef]

30. Cha, Y.J.; Shim, M.-P.; Kim, S.K. The Four Major Rivers Restoration Project (Korea). In Water Planning in the Transition to a Green Economy, Proceedings of Water in the Green Economy in Practice: Toward Rio +20, Zaragoza, Spain, 3-5 October 2011; UN-Water Decade Programme on Advocacy and Communication: Zaragoza, Spain, 2012.

31. Choi, I.; Kim, H.; Shin, H.; Tenhunen, J.; Nguyen, T.T. Economic Valuation of the Aquatic Biodiversity Conservation in South Korea: Correcting for the Endogeneity Bias in Contingent Valuation. Sustainability 2017, 9, 930. [CrossRef]

32. Ishiwatari, M.; Wataya, E.; Shin, T.; Kim, D.; Song, J.; Kim, S. Promoting green growth through water resources management: The case of Republic of Korea. In Green Growth in Action Knowledge Note Series, 3; World Bank Group: Washington, DC, USA, 2016. 
33. Nguyen, T.T.; Ruidish, M.; Koellner, T.; Tenhunen, J. Synergies and tradeoffs between nitrate leaching and net farm income: The case of best nitrogen management practices in South Korea. Agric. Ecosyst. Environ. 2014, 186, 160-169. [CrossRef]

34. Kim, D.-W.; Byun, H.-R.; Choi, K.-S.; Oh, S.-B. A spatiotemporal analysis of historical droughts in Korea. J. Appl. Meteorol. Climatol. 2011, 50, 1895-1912. [CrossRef]

35. Ha, K.-J.; Heo, K.-Y.; Lee, S.-S.; Yun, K.-S.; Jhun, J.-G. Variability in the East Asian Monsoon: A review. Meteorol. Appl. 2012, 19, 200-215. [CrossRef]

36. Chung, Y.-S.; Yoon, M.-B.; Kim, H.-S. On climate variations and changes observed in South Korea. Clim. Chang. 2004, 66, 151-161. [CrossRef]

37. National Institute of Environmental Research (NIER). Korean Climate Change Assessment Report 2010; National Institute of Environmental Research: Seoul, Korea, 2010.

38. Korea Meteorological Administration (KMA). Annual Report. 2014. Available online: http:/ /web.kma.go. kr/download_01/Annual_Report_2014.pdf (accessed on 28 February 2017).

39. Choi, G.; Kwon, W.-T.; Boo, K.-O.; Cha, Y.-M. Recent spatial and temporal changes in means and extreme events of temperature and precipitation across the Republic of Korea. J. Korean Geogr. Soc. 2008, 43, 681-700.

40. Im, E.-S.; Lee, B.-J.; Kwon, J.-H.; In, S.-R.; Han, S.-O. Potential increase of flood hazards in Korea due to global warming from a high-resolution regional climate simulation. Asia-Pac. J. Atmos. Sci. 2012, 48, 107-113. [CrossRef]

41. Im, E.-S.; Choi, Y.-W.; Ahn, J.-B. Robust intensification of hydroclimatic intensity over East Asia from multi-model ensemble regional projections. Theor. Appl. Climatol. 2016. [CrossRef]

42. Ministry of Environment. Ecorea-Environmental Review 2015, Korea, Volume 1; Ministry of Environment: Sejong-City, Korea, 2015.

43. Nam, W.-H.; Hayes, M.J.; Svoboda, M.D.; Tadesse, T.; Wilhite, D.A. Drought hazard assessment in the context of climate change for South Korea. Agric. Water Manag. 2015, 160, 106-117. [CrossRef]

44. World Water Assessment Programme (WWAP). The United Nations World Water Development Report 4-Managing Water under Uncertainty and Risk; UNESCO: Paris, France, 2012.

45. Kim, B. Eutrophication of Freshwater Ecosystems in Korea, and the Effect of Monsoon. In Ecology of Korea; Lee, D.W., Jin, V., Choe, J.C., Son, Y.H., Lee, H.-Y., Hong, S.K., Ihm, B.-S., Eds.; Bumwoo: Seoul, Korea, 2002; pp. 385-399.

46. Ministry of Environment. Some Success Stories of Korean Environmental Policies-Keeping Water Clean; Ministry of Environment: Sejong-City, Korea, 2011.

47. Yang, J.-E.; Ryu, J.-H.; Kim, S.-J.; Chung, D.-Y. Management strategies to conserve soil and water qualities in the sloping uplands in Korea. J. Agric. Sci. 2010, 37, 435-449.

48. Kim, B.; Park, J.-H.; Hwang, G.; Jun, M.-S.; Choi, K. Eutrophication of reservoirs in South Korea. Limnology 2001, 2, 223-229. [CrossRef]

49. Lee, J.-Y. A hydrological analysis of current status of turbid water in Soyang River and its mitigation. J. Soil Groundw. Environ. 2008, 13, 85-92.

50. Park, J.-H.; Inam, E.; Abdullah, M.H.; Agustiyani, D.; Duan, L.; Hoang, T.T.; Kim, K.-W.; Kim, S.D.; Nguyen, M.H.; Pekthong, T.; et al. Implications of rainfall variability for seasonality and climate-induced risks concerning surface water quality in East Asia. J. Hydrol. 2011, 400, 323-332. [CrossRef]

51. Bae, D.-H.; Jung, I.W.; Chang, H. Potential changes in Korean water resources estimated by high-resolution climate simulation. Clim. Res. 2008, 35, 213-226. [CrossRef]

52. Jo, K.-W.; Lee, H.-J.; Park, J.-H.; Owen, J.S. Effects of monsoon rainfalls on surface water quality in a mountainous watershed under mixed land use. Korean J. Agric. For. Meteorol. 2010, 12, 197-206. [CrossRef]

53. Kim, B.-S.; Kim, B.-K.; Kwon, H.-H. Assessment of the impact of climate change on the flow regime of the Han River basin using indicators of hydrologic alteration. Hydrol. Process. 2011, 25, 691-704. [CrossRef]

54. Shin, H.J.; Kim, H.N.; Jeon, C.H.; Jo, M.W.; Nguyen, T.T.; Tenhunen, J. Benefit transfer for water management along the Han River in South Korea using Meta-regression analysis. Water 2016, 8, 492. [CrossRef]

55. Nguyen, T.T. Gains and losses in ecosystem services: Trade-off and efficiency perspectives. Habilitation Thesis, University of Bayreuth, Bayreuth, Germany, 2015. 
56. Pereira, H.M.; Reyers, B.; Watanabe, M.; Bohensky, E.; Foale, S.; Palm, C.; Espaldon, M.V.; Armenteras, D.; Tapia, M.; Rincón, A.; et al. Condition and trends of ecosystem services and biodiversity. In Ecosystems and Human Well-Being: Multi Scale Assessments_Volume 4-Findings of the Sub-global Assessments Working Group of the Millennium Ecosystem Assessment; Capistrano, D., Samper, C., Lee, M.J., Raudsepp-Hearne, C., Eds.; Island Press: Washington, DC, USA, 2005; pp. 171-203.

57. Van Jaarsveld, A.S.; Biggs, R.; Scholes, R.J.; Bohensky, E.; Reyers, B.; Lynam, T.; Musvoto, C.; Fabricius, C. Measuring conditions and trends in ecosystem services at multiple scales: The Southern African Millennium Ecosystem Assessment (SAfMA) experience. Philos. Trans. R. Soc. Lond. B 2005, 360, 425-441. [CrossRef] [PubMed]

58. Elmqvist, T.; Tuvendal, M.; Krishnaswamy, J.; Hylander, K. Managing Trade-Offs in Ecosystem Services-Ecosystem Services Economics Working Paper Series No. 4; UNEP DEPI: Nairobi, Kenya, 2011.

59. Choi, I.; Shin, H.; Nguyen, T.T.; Tenhunen, J. Water policy reforms in South Korea: A historical review and ongoing challenges for sustainable water governance and management. Water 2017. under review.

60. Food and Agriculture Organization of the United Nations (FAO). Ecosystem Services \& Biodiversity (ESB). 2017. Available online: http://www.fao.org/ecosystem-services-biodiversity/en/ (accessed on 1 November 2016).

61. Hewlett, J.D. Principles of Forest Hydrology; University of Georgia Press: Athens, GA, USA, 1982.

62. Chang, M. Forest Hydrology: An Introduction to Water and Forests; CRC Press: Boca Raton, FL, USA, 2006.

63. Chang, H.; Franczyk, J.; Kim, C. What is responsible for increasing flood risks? The case of Gangwon Province, Korea. Nat. Hazards 2009, 48, 339-354. [CrossRef]

64. Park, M.S.; Youn, Y.-C. Reforestation policy integration by the multiple sectors toward forest transition in the Republic of Korea. For. Policy Econom. 2017, 76, 45-55. [CrossRef]

65. Bae, J.S.; Joo, R.W.; Kim, Y.-S. Forest transition in South Korea: Reality, path and drivers. Land Use Policy 2012, 29, 198-207. [CrossRef]

66. Lee, D. The forest sector's contribution to a "low carbon, green growth" vision in the Republic of Korea. Unasylva 2012, 63, 9-16.

67. Statistics Korea. Korea's Green Growth Based on OECD Green Growth Indicators; Narai Publishing Group: Daejeon, Korea, 2012.

68. Korea Forest Service. National Report on Sustainable Forest Management in Korea 2009. 2009. Available online: http:/ / www.rinya.maff.go.jp/j/kaigai/pdf/2009p_4_k.pdf (accessed on 26 January 2016).

69. Kim, K.-Y. Implementation of a Watershed Management System: Four Major River Basins. Korea Environ. Policy Bull. 2003, 1, 1-24.

70. Lee, B.-K. Water environment management master plan outline (2006 2015)—Clean water, Eco River 2015. Korea Environ. Policy Bull. 2006, 4, 1-12.

71. Ministry of Environment. Ecorea-Environmental Review 2015, Korea, Volume 2; Ministry of Environment: Sejong-City, Korea, 2015.

72. Kim, I.-J.; Kim, H. Four Major River Restoration Project of Republic of Korea. Korea Environ. Policy Bull. 2009, 7, 1-12.

73. Jones, R.S.; Yoo, B. Achieving the "Low Carbon, Green Growth" Vision in Korea-OECD Economics Department Working Papers No. 964; OECD Publishing: Paris, France, 2012.

74. Kim, H. Water quality forecasting system. Korea Environ. Policy Bull. 2013, 11, 1-12.

75. Lee, G.B.; Kim, Y.H.; Ka, P.S.; Lee, S.W.; Byun, D.G. A case study on the system optimization of hydro power generators that are a part of the Four Major Rivers Restoration Project. J. Int. Counc. Electr. Eng. 2013, 3, 348-352. [CrossRef]

76. Yoo, S.-H.; Park, D. The effects of the Four Major Rivers Restoration Project on regional economy. J. Wetl. Res. 2013, 15, 159-164. [CrossRef]

77. Ministry of Environment. Ministry of Environment, Republic of Korea; Ministry of Environment: Sejong-City, Korea, 2015.

78. Ahn, J.M.; Lee, S.; Kang, T. Evaluation of dams and weirs operating for water resource management of the Geum River. Sci. Total Environ. 2014, 478, 103-115. [CrossRef] [PubMed]

79. Park, Y.-S.; Kwon, Y.-S.; Hwang, S.-J.; Park, S. Characterizing effects of landscape and morphometric factors on water quality of reservoirs using a self-organizing map. Environ. Model. Softw. 2014, 55, $214-221$. [CrossRef] 
80. Jun, K.S.; Kim, J.S. The Four Major Rivers Restoration Project: Impacts on river flows. KSCE J. Civ. Eng. 2011, 15, 217-224. [CrossRef]

81. Kim, S.; Noh, H.; Jung, J.; Jun, H.; Kim, H.S. Assessment of the impacts of global climate change and regional water projects on streamflow characteristics in the Geum River Basin in Korea. Water 2016, 8, 91. [CrossRef]

82. Han, H. Authoritarian environmentalism under democracy: Korea's river restoration project. Environ. Polit. 2015, 24, 810-829. [CrossRef]

83. Kim, H.; Han, J.-K.; Park, J. Green Growth and Green Jobs in Korea: Potentials and Perspectives. 2012. Available online: http:/ / www.fes-asia.org/media/publication/2012_GreenGrowthAndGreenJobsInKorea_ FES-EoT_Study_Hyun-woo_Jae-kak_Jin-hee.pdf (accessed on 23 May 2016).

84. Lah, T.; Park, Y.; Cho, Y.J. The Four Major Rivers Restoration Project of South Korea-An assessment of its process, program, and political dimensions. J. Environ. Dev. 2015, 24, 375-394. [CrossRef]

85. Lee, Y.; Chang, H.; Hong, Y. Is a costly river restoration project beneficial to the public? Empirical evidence from the Republic of Korea. Desal. Water Treat. 2015, 54, 3696-3703. [CrossRef]

86. Normile, D. Restoration or devastation? Science 2010, 327, 1568-1570. [CrossRef] [PubMed]

87. Park, J.S. Inland fisheries resource enhancement and conservation in the republic of Korea. In Inland Fisheries Resource Enhancement and Conservation in Asia; Weimin, M., De Silva, S., Davy, B., Eds.; FAO: Bangkok, Thailand, 2010; p. 80.

88. Lee, H.; Koo, M.-H.; Kim, K.; Kim, Y. Spatio-temporal variations in stream-Aquifer interactions following construction of weirs in Korea. Groundwater 2016, 54, 448-458. [CrossRef] [PubMed]

89. Kim, J.-S.; Yoon, S.-K.; Choi, M.; Moon, Y.-I. A case study of regional risk assessment of river restoration projects: Nakdong River Basin, South Korea. J. Water Clim. Chang. 2015, 6, 628-637. [CrossRef]

90. Global Green Growth Institute. Korea's Green Growth Experience: Process, Outcomes and Lessons Learned; Global Green Growth Institute: Seoul, Korea, 2015.

91. Jänicke, M. Green growth: From a growing eco-industry to economic sustainability. Energy Policy 2012, 48, 13-21. [CrossRef]

92. Choi, H.T. Effect of forest growth and thinning on the long-term water balance in a coniferous forest. Korean J. Agric. For. Meteorol. 2011, 13, 157-164. [CrossRef]

93. Jones, R.S.; Yoo, B. Korea's Green Growth Strategy: Mitigating Climate Change and Developing New Growth Engines-OECD Economics Department Working Papers No. 798; OECD Publishing: Paris, France, 2011.

94. Kwon, S.-D.; Park, Y.-K.; Kim, E.-H. Study on Forest Functions Classification using GIS-Chunyang National Forest Management Planning. J. Korean Assoc. Geogr. Inf. Stud. 2008, 11, 10-21.

95. Korean Rural Economics Institute. Agriculture in Korea 2014; Korean Rural Economics Institute: Naju, Korea, 2014.

96. Organisation for Economic Co-operation and Development (OECD). Meeting the Water Reform Challenge; OECD Publishing: Paris, France, 2012.

97. Kong, I.; Lee, D. Establishment of priority forest areas based on hydrological ecosystem services in northern Vietnam. J. Korea Soc. Environ. Restor. Technol. 2014, 17, 29-41. [CrossRef]

98. Nguyen, T.T.; Pham, V.D.; Tenhunen, J. Linking regional land use and payments for forest hydrological services: A case study of Hoa Binh Reservoir in Vietnam. Land Use Policy 2013, 33, 130-140. [CrossRef]

99. Kang, M.G.; Park, S.W. An adaptive watershed management assessment based on watershed investigation data. Environ. Manag. 2015, 55, 1006-1021. [CrossRef] [PubMed]

100. Yun, S.-J. Experts' Social Responsibility in the process of Large-Scale Nature-Transforming National Projects: Focusing on the case of the Four Major Rivers Restoration Project in Korea. Dev. Soc. 2014, 43, 109-141.

101. Costanza, R.; d'Arge, R.; De Groot, R.; Farber, S.; Grasso, M.; Hannon, B.; Limburg, K.; Naeem, S.; O’Neill, R.V.; Paruelo, J.; et al. The value of the world's ecosystem services and natural capital. Nature 1997, 387, 253-260. [CrossRef]

102. De Groot, R.S. Environmental functions as a unifying concept for ecology and economics. Environmentalist 1987, 7, 105-109. [CrossRef]

103. Millennium Ecosystem Assessment (MA). Ecosystems and Human Well-Being: Synthesis; Island Press: Washington, DC, USA, 2005.

104. Postel, S.L.; Thompson, B.H. Watershed protection: Capturing the benefits of nature's water supply services. Nat. Resour. Forum 2005, 29, 98-108. [CrossRef] 
105. Nguyen, T.T.; Tenhunen, J. Climate change and crop production for bioenergy linkage at local scale: Challenges and implications. Int. J. Clim. Chang. Str. 2013, 5, 324-343. [CrossRef]

106. The Economics of Ecosystems and Biodiversity (TEEB). Économie des Écosystèmes et de la Biodiversité: Intégration de L'économie de la Nature-Une Synthèse de L'approche, des Conclusions et des Recommandations de la TEEB; TEEB: Geneva, Switzerland, 2010. 